\title{
THE PRESIDENT'S ADDRESS
}

\author{
BY J. D. B. HARrison \\ Dominion Forest Service, Ottawa, Ontario
}

$\mathrm{D}$

URING the past year the tide of war reached its ebb and commenced to flow in favour of the United Nations. There have been great changes in requirements for war supplies but no slackening in the need for forest products. Demands made on the Canadian lumber and pulp and paper industries have not been reduced; on the contrary, they have increased. The need for primary forest products is as great or greater than ever, though actual production in 1943 was somewhat reduced because of the strained manpower situation.

Severe restrictions have been imposed on civilian use of lumber and paper and, in some sections of Canada, there have been serious shortages of fuelwood. The scarcity of forest products has given an unpleasant surprise to the average Canadian. There is evidence to show that this shock, if I may so call it, has resulted in a degree of public interest in our forest resources which is greater now than at any previous time. We have here a fact which members of this Society should constantly bear in mind.

To pass from the general situation to the affairs of the Society itself, I first want to compliment and thank our secretary-treasurer, Mr. Fenwick, and the chairman of the Editorial Board, Mr. Druce, for the excellent work they have done on our behalf during the past year. We are much indebted to them. I also want to thank Mr. Druce and the other members of the annual meeting committee for organizing and arranging accommodation for this meeting.

A year ago we hoped that some of the governmental plans relating to forest resources in the post-war period would be made public during 1943. Your special committee on Rehabilitation was asked to remain in being and its membership was increased, in order that any comments which seemed desirable with respect to such plans might be prepared for your consideration. No plans have been published yet but your committee will be asked to study any that become available in 1944.

At these meetings we will hear a review of the status of planning activi. ties throughout the Dominion and discussions respecting the post-war forestry problems of three chief branches of our forest industry. We will then be in possession of information which should help us, both as members of the Society and as individuals, to exert our future efforts in the most profitable directions.

To-morrow afternoon the Executive will make its report on action taken with respect to resolutions adopted at the last meeting. One of those resolutions concerned the provision, by the Canadian Legion Education Services, of a course in Forestry for the Armed Forces. You will be glad to know that this course is nearly completed and its four text booklets will probably be printed in March and April. The Society played an important part in 
the preparation of these booklets. I believe these will be the first text books on general forestry to be published in Canada.

The most important difference between 1943 and previous years, from the Society's point of view, lay in the existence of the Statement of Forest Policy formally adopted a year ago. Over 700 English copies were distribu. ted to the trade press and to daily and weekly newspapers. Many important publications, including the Montreal Gazette and the Financial Post, printed extensive reviews. The British Columbia Lumberman printed the whole state. ment, with illustrations. A French translation was undertaken and has recently been sent to newspapers published in the French language. Copies were placed in the hands of all Ministers of the Crown who administer forest resources, the chairmen of committees of the House of Commons and the Senate considering post-war matters and the Sub-Committee on Natural Re. sources of the Committee on Reconstruction.

The last-mentioned committee has reported to the Dominion Government but its findings are not yet published. I know, however, that our Statement of Forest Policy was carefully considered by the committee and, no doubt, it had its influence on their report. We were fortunate that it was available in time.

I should like to make a few suggestions respecting the future use of the statement on policy. It can be ignored and allowed to gather dust; but I don't think members of the Society will be content with that. Alternatively, it can be made a solid foundation for forestry progress throughout the Dominion.

As you know, the statement itself is drawn in general terms. Questions as to what should be done are answered but there is no mention as to how these things should be done or who should do them. The reason for excluding "how" and "who" was simple. Canada is so large, and its forest and other conditions are so varied, that it was impossible to provide answers which would be equally applicable everywhere.

Further progress in the formulation of definite policies can only be made on a regional basis. There is not one forest administration in Canada, but nine or ten different administrations. You all know that if any definite goal is to be attained, it can only be reached by taking into account actual conditions, personalities, and politics. Thus, as far as this Society is concerned, further progress depends chiefly on the Sections. It will be the duty of the national Society to support their constructive efforts. We should also work for that degree of mutual co-operation and assistance between all forest authorities, provincial and Dominion, which is essential to the national inter. est.

The message sent to this meeting by His Excellency the Governor-General may well serve as an inspiration to all of us to increase our efforts towards the objectives set forth in our Constitution-increased technical competence and professional co-operation among ourselves, and better forest management in our country. What each of us contributes to the Society will be the measure of what each receives from it. We are doing our best under the abnormal conditions of war; may we be found equal to the new responsibilities that peace will bring. 